\title{
An Efficient Ex Vitro Rooting and Acclimatization Method for Horticultural Plants Using Float Hydroculture
}

\author{
Doina Clapa ${ }^{1}$ \\ In Vitro Culture Laboratory, Fruit Research Station Cluj, Horticultorilor \\ no. 5, Cluj-Napoca, Romania
}

\begin{abstract}
Alexandru Fira
In Vitro Culture Laboratory, Fruit Research Station Cluj, Horticultorilor no. 5, Cluj-Napoca, Romania; and the Department of Experimental Biology, Babes-Bolyai University, Clinicilor 5-7, Cluj-Napoca, Romania
\end{abstract}

\author{
Nirmal Joshee \\ Agricultural Research Station, Fort Valley State University, Fort Valley, \\ GA 31030
}

Additional index words. cell trays, hydroculture, micropropagation, perlite, tissue culture

\begin{abstract}
This article presents a new acclimatization method, ex vitro acclimatization in float hydroculture. This protocol ensures the ex vitro acclimatization of the plantlets obtained in vitro in the rooting stage or the ex vitro rooting and acclimatization of the shoots obtained in the multiplication stage. Our hydroculture method is different from the techniques of flotation hydroculture because no fertilizers or plant growth regulators or other biostimulators are used and water oxygenation by bubbling is not provided. Ex vitro rooting and acclimatization in one stage without an in vitro rooting stage in floating cell trays was successfully carried out in Rubus fruticosus and Rosa hybrida cultivars, whereas ex vitro acclimatization of in vitro-rooted plantlets was successfully carried out in Rubus idaeus, Ribes nigrum, Prunus cerasus $\times$ P. canescens, Lycium barbarum (Goji berry), Amelanchier canadensis, Drosera rotundifolia, Drosera capillaris, and Nephrolepis sp. In another set of experiments, the floating cell trays were replaced with layers of floating perlite and the latter method was also tested for non-rooted shoots obtained in vitro in the multiplication stage or rooted plantlets obtained in the rooting stage. Direct ex vitro rooting in floating perlite was successful in 'Tayberry' (Rubus fruticosus $\times$ Rubus idaeus) (78.12\% rooting); Amelanchier canadensis, Rubus fruticosus 'Chester', Rubus idaeus 'Erntesegen', Vaccinium macrocarpon, and Vaccinium corymbosum with rooting percentages above $80 \%$; and Rubus idaeus 'Willamette' and Rosa hybrida 'Cristiana' with rooting percentages above $80 \%$.
\end{abstract}

Ex vitro acclimatization is an important stage during in vitro plant propagation, because it deals with gradual transition from the artificial culture conditions to the natural living environment. In the acclimatization stage it is necessary to ensure optimal culture conditions to obtain high survival rates. The usual methods of ex vitro acclimatization use various types of containers filled with different types of potting mix (peat, perlite, soil, vermiculite individually or in optimized

Received for publication 27 Dec. 2012. Accepted for publication 20 June 2013

This work was possible with the financial support of the Sectoral Operational Programme for Human Resources Development 2007-2013, cofinanced by the European Social Fund, under project number POSDRU/107/1.5/S/76841 entitled "Modern Doctoral Studies: Internationalization and Interdisciplinarity."

${ }^{1}$ To whom reprint requests should be addressed; e-maildoinaclapa@yahoo.com combination) as transplanting substrates as well as artificial culture areas (greenhouses, tunnels, growth rooms) in which air humidity is kept at high levels to prevent the dehydration of the plantlets transferred ex vitro.

For acclimatization, generally, plantlets rooted in vitro on media favorable for rooting are used (Bobrowski et al., 1996; Erig and Schuch, 2005; Fira et al., 2009; Najaf-Abadi and Hamidoghli, 2009; Radmann et al., 2003; Ružic and Laziž, 2006, 2007). Hazarika (2003), in a review on ex vitro acclimatization, mentions that during transition, better plantlet development, stomata functioning, and synthesis of epicuticular wax can be achieved by lowering air humidity in the culture vessels, by the use of growth retardants like paclobutrazol or Cycocel, and the use of antitranspirants. Examples of successful direct ex vitrorooted plants are citrus, tea, walnut, peach, tobacco, and brinjal. The author further suggests application of direct ex vitro rooting of shoots deriving from the in vitro multiplication stage to reduce costs. Cristea (2010) mentions the usefulness of photoautotrophic micropropagation for the improvement of rhizogenesis and acclimatization process.

Rohr et al. (2003) discussed the morphological and anatomical anomalies of in vitrocultured plants, like the absence of cuticle and stomata that should protect the plantlets from desiccation, as well as the lack of a properly developed root system. They also mention the two main approaches used for ex vitro acclimation: reducing water stress and helping the plantlets become autotrophic. They further offer examples for the beneficial effect of improved aeration during in vitro culture and the use of mycorrhiza for ex vitro acclimatization.

In this study, the ex vitro acclimatization of in vitro-rooted plantlets was studied in float hydroculture. We also studied the direct ex vitro rooting and acclimatization of in vitroraised shoots harvested during the multiplication stage. In the latter case, both rooting and acclimatization were carried out ex vitro in the same stage.

Another method for the ex vitro acclimatization of several horticultural species was ex vitro acclimatization in floating perlite beds. This technique derives from the technique of acclimatization in flooded perlite in plastic trays (Tromble, 2011).

Most flotation hydroponics systems are made of long, rectangular cemented or wooden tanks and lined with waterproof material, which contain the nutritive solution. On the surface of the nutritive solution, there are floats made of polystyrene or other materials that sustain the plants (Sheikh, 2006; Sweat et al., 2003).

The technique of rooting ex vitro in floating cell trays was inspired from a method used for tomato and tobacco seedlings and for lettuce (Peek and Reed, 2008; Reed, 2009; Ross and Teffeau, 1995; Tyson et al., 1999). The method of float hydroculture presented in our article is different from the previous protocols because no fertilizers, plant growth regulators, or biostimulators were used and aeration was not provided. In our float hydroculture experiments, no porous substrate like peat, vermiculite, or peat and perlite mixture was used for supporting the plantlets. Air humidity was also not maintained at a certain level mechanically or otherwise.

The aim of this study was to test the efficiency of the novel ex vitro acclimatization techniques set up by the authors at the Fruit Research Station Cluj for the ex vitro acclimatization of several important horticultural species and cultivars. Another objective was to carry out direct ex vitro rooting to provide a means for avoiding the in vitro rooting stage where it was the case, by direct ex vitro rooting in float hydroculture or in floating perlite. Both ex vitro acclimatization techniques (float hydroculture and floating perlite beds) are radically new because they do not require the maintenance of high relative humidity around the plantlets to be acclimatized and the maintenance of the substrate's humidity by irrigation is not required, because the substrate maintains its humidity by 
passively absorbing water from below in the case of floating perlite beds and, in the case of float hydroculture, the substrate is the water itself from the vessels used for acclimatization.

\section{Material and Method}

\section{Plant material}

The various plant species and cultivars studied in this set of experiments belong to various botanical families and they are either ornamental or fruit species. Rosa hybrida 'Red Bells' and 'Cristiana' are procumbent roses; Nephrolepis sp., Drosera capillaris, and Drosera rotundifolia are carnivorous species used as ornamentals. Amelanchier canadensis 'Rainbow Pillar' is an ornamental as well as fruit shrub. 'Gisela 5' (Prunus cerasus $\times$ Prunus canescens) is a dwarf cherry rootstock. Rubus idaeus, Rubus fruticosus, Vaccinium macrocarpon, and Vaccinium corymbosum as well as 'Tayberry' (Rubus fruticosus $\times$ Rubus idaeus) are important fruit shrubs. Lycium barbarum is an important fruit shrub, which also has medicinal properties.

To test the two acclimatization methods, in vitro-cultured plantlets were used, either elongated shoots from the multiplication stage or plantlets from the rooting media (Table 1). The media used for the in vitro cultures consisted of modified Murashige and Skoog (1962) (MS) or Woody Plant Medium (WPM) (Lloyd and McCown, 1981) with plant growth regulators according to the species and culture stage (Table 1). The MS basal medium codenamed MSm contained MS salts at full concentration, $100 \mathrm{mg} \cdot \mathrm{L}^{-1}$ Myoinositol, $1 \mathrm{mg} \cdot \mathrm{L}^{-1}$ vitamin $\mathrm{B}_{1}, 0.5 \mathrm{mg} \cdot \mathrm{L}^{-1}$ vitamin $\mathrm{B}_{6}, 0.5 \mathrm{mg} \cdot \mathrm{L}^{-1}$ nicotinic acid, $30 \mathrm{~g} \cdot \mathrm{L}^{-1}$ sugar (Coronitsa, Romania) and were gelled with $6 \mathrm{~g} \cdot \mathrm{L}^{-1}$ Plant Agar (Duchefa Biochemie BV, The Netherlands). MSs was similar to MSm but gelled with $50 \mathrm{~g} \cdot \mathrm{L}^{-1}$ wheat starch (Compania Indiilor Orientale SRL, Romania).

The modified WPM consisted of WPM salts without (FeNaEDTA as an iron source),
$100 \mathrm{mg} \cdot \mathrm{L}^{-1} \mathrm{FeNaEDDHA}$ as an iron source, $100 \mathrm{mg} \cdot \mathrm{L}^{-1}$ myo-inositol, $2 \mathrm{mg} \cdot \mathrm{L}^{-1}$ vitamin $\mathrm{B}_{1}, 1 \mathrm{mg} \cdot \mathrm{L}^{-1}$ vitamin $\mathrm{B}_{6}, 1 \mathrm{mg} \cdot \mathrm{L}^{-1}$ nicotinic acid, and $30 \mathrm{~g} \cdot \mathrm{L}^{-1}$ sugar (Coronitga, Romania) and were gelled with $6 \mathrm{~g} \cdot \mathrm{L}^{-1}$ Plant Agar (Duchefa Biochemie BV, The Netherlands). All the components were added to the media before sterilization by autoclavation. The $\mathrm{pH}$ of the media was adjusted before adding the gelling agents.

\section{Float hydroculture}

This method used cell trays fitted with floats (Styrofoam, polyurethane foam, or other materials) placed on the surface of a tub filled with water. In this set of experiments, floats made of Styrofoam were used. Care was taken in such a way that one-third to half of the basal part of the shoots placed into the cells is submerged into the water. During the experiments, the water was not replaced. The water in the tubs was only replenished, if it was the case, to maintain water level. For most species, ordinary tap water with $\mathrm{pH}$ $\approx 7.0$ was used. For some acidophilous species (Vaccinium macrocarpon and Vaccinium corymbosum), water $\mathrm{pH}$ was adjusted to 4.5 using $\mathrm{HCl}$. Ex vitro acclimatization was accomplished in 4 weeks; during which the plantlets grew, they also generated new roots and finally they became suitable for transplanting into pots with soil mix. Table 2 shows the physical and chemical characteristics of the tap water in Cluj-Napoca city, that was used in our acclimatization experiments. Various steps in the process are as follows. The tub is filled with tap water and a cell tray is prepared by fixing some floats on the underside of the cell tray (Fig. 1). The size of the cells should be $3 / 3.5 \mathrm{~cm}$ or $1 / 1 \mathrm{~cm}$ for plantlets smaller than $2 \mathrm{~cm}$. Then the cell trays are placed on the water surface in the tubs.

Elongated shoots are harvested from in vitro cultures in the multiplication or in the rooting stage. Shoots are gently washed with warm water to remove the remnants of nutritive media and placed into the cells (15 to 25 shoots per $3 / 3.5-\mathrm{cm}$ cell depending on size and species; for blackberry, 15 to 20 shoots/bunch). For the smaller cells that are $1 \mathrm{~cm}$ in diameter, there should be four to six shoots/cell. The bunches should sit upright in the cells without being compressed to cause damage to the shoots and they should not be loose so that the bunch should not fall apart. The bunch should be just tight enough to stay safely in the cells, where one-third to half of the base of the shoots should stay submerged in the water. When using plantlets rooted in vitro, place bunches of plantlets into the cells in such a way that the water covers the roots to avoid desiccation. Depending on species and size, three to 10 rooted plantlets per 3/ $3.5-\mathrm{cm}$ cell should be accommodated. The bunches should sit upright as loose plugs in the cells, and care should be taken not to damage the roots. At this point the tubs are transferred to a growth room with a controlled environment $\left(23 \pm 3{ }^{\circ} \mathrm{C}, 27-32.4 \mu \mathrm{mol} \cdot \mathrm{m}^{-2} \cdot \mathrm{s}^{-1}\right.$, 16-h photoperiod), or into the greenhouse, or under shelters in open air, depending on the facility available and plant species. The growth room proved to be suitable for all the species we studied. Rubus fruticosus could be rooted ex vitro and acclimatized in open air also (Fira et al., 2011).

\section{Ex vitro rooting and acclimatization of non-rooted shoots from the multiplication stage, in float hydroculture}

In this case, shoots derived from the multiplication stage were grouped into bunches and introduced into floating cell trays. This method was tested for Rubus fruticosus 'Loch Ness' and 'Chester', Rubus idaeus 'Willamette', 'Tayberry' (Rubus fruticosus $\times$ Rubus idaeus), Lycium barbarum 'Ning Xial', Amelanchier canadensis Rainbow Pillar', Rosa hybrida 'Cristiana' and 'Red Bells', and Stevia rebaudiana. The multiplication

Table 1. The species, cultivars, and the composition of culture media for the plant material used for acclimatization.

\begin{tabular}{|c|c|c|c|}
\hline & Species/cultivar & $\begin{array}{l}\text { Multiplication } \text { media }^{z} / \text { in } \\
\text { vitro culture period }\end{array}$ & $\begin{array}{l}\text { Rooting media/in } \\
\text { vitro culture period }\end{array}$ \\
\hline 1 & Rubus fruticosus/Loch Ness & $\mathrm{MSs}+2.22 \mu \mathrm{M} \mathrm{BAP} / 2$ months & - \\
\hline 2 & Rubus fruticosus/Chester & $\mathrm{MSs}+2.22 \mu \mathrm{M} \mathrm{BAP} / 3$ months & - \\
\hline 3 & Rubus idaeus/Willamette & $\mathrm{MSs}+2.22 \mu \mathrm{M} \mathrm{BAP} / 2$ months & MSs/1 month \\
\hline 4 & Rubus idaeus/Erntesegen & $\mathrm{MSs}+2.22 \mu \mathrm{M} \mathrm{BAP} / 2$ months & - \\
\hline 5 & Tayberry & $\mathrm{MSm}+2.22 \mu \mathrm{M}$ BAP $+3 \mathrm{~g} \cdot \mathrm{L}^{-1}$ Plant Agar $/ 3$ months & - \\
\hline 6 & Ribes nigrum/Tisel & $\mathrm{MSm}+3 \mathrm{~g} \cdot \mathrm{L}^{-1}$ Plant Agar $/ 2$ months & - \\
\hline 7 & Vaccinium corymbosum/Duke & $\begin{array}{l}\text { WPMm }+24.59 \mu \mathrm{M} 2-\mathrm{Ip}+20 \mathrm{mg} \cdot \mathrm{L}^{-1} \\
\text { ascorbic acid } / 3 \text { months }\end{array}$ & - \\
\hline 8 & $\begin{array}{l}\text { Vaccinium corymbosum/Elliot, } \\
\text { Hannahs Choice }\end{array}$ & $\mathrm{WPMm}+24.59 \mu \mathrm{M} 2-\mathrm{iP} / 3$ months & \\
\hline 9 & Vaccinium macrocarpom/Pilgrim & $\mathrm{WPMm}+24.59 \mu \mathrm{M} 2-\mathrm{iP} / 3$ months & - \\
\hline 10 & Lycium barbarum/Ningxia 1 & $\mathrm{MSs}+1.33 \mu \mathrm{M} \mathrm{BAP} / 2$ months & $\mathrm{MSs} / 3$ weeks \\
\hline 11 & Amelanchier canadensis/Rainbow Pillar & $\mathrm{MSs}+3.10 \mu \mathrm{M} \mathrm{BAP} / 3$ months & $\mathrm{MSs}+2.46 \mu \mathrm{M} \mathrm{IBA} / 6$ weeks \\
\hline 12 & $\begin{array}{l}\text { Prunus cerasus } \times \text { Prunus } \\
\text { canescens } / \text { Gisela } 5\end{array}$ & $\mathrm{MSm}+1.33 \mu \mathrm{M}$ BAP $+3 \mathrm{~g} \cdot \mathrm{L}^{-1}$ Plant agar $/ 6$ weeks & $\begin{array}{l}\mathrm{MSm}+4.92 \mu \mathrm{M} \text { IBA }+3 \mathrm{~g} \cdot \mathrm{L}^{-1} \\
\quad \text { Plant Agar } / 1 \text { month }\end{array}$ \\
\hline 13 & Rosa hybrida/Cristiana & $\mathrm{MSs}+2.22 \mu \mathrm{M} / 3$ months & - \\
\hline 14 & Drosera capillaris & MSs/ 5 months & - \\
\hline 15 & Drosera rotundifolia & $\mathrm{MSm}+5 \mathrm{~g} \cdot \mathrm{L}^{-1}$ Plant Agar $/ 3$ months & - \\
\hline 16 & Nephrolepis sp. & $\mathrm{MSm}+2.22 \mu \mathrm{M} \mathrm{BAP}+6 \mathrm{~g} \cdot \mathrm{L}^{-1}$ Plant Agar $/ 3$ months & $\mathrm{MSm}+6 \mathrm{~g} \cdot \mathrm{L}^{-1}$ Plant Agar $/ 3$ months \\
\hline 17 & Stevia rebaudiana & $\mathrm{MSm}+2.22 \mu \mathrm{M}$ BAP $+5 \mathrm{~g} \cdot \mathrm{L}^{-1}$ Plant Agar $/ 2$ months & $\mathrm{MSm}+5 \mathrm{~g} \cdot \mathrm{L}^{-1}$ Plant Agar/1 month \\
\hline
\end{tabular}

${ }^{\mathrm{z}}$ Murashige and Skoog (1962) (MS) or Woody Plant Medium (WPM) in the following treatments: MSm = modified Murashige and Skoog gelled with agar; MSs = modified Murashige and Skoog gelled with wheat starch. Growth regulators: BAP = benzyladenine; IBA = indole-butyric acid; 2-iP = 2- isopentenyladenine. 
media from which the shoots derived and the in vitro culture period are presented in Table 1. All the experiments were carried out in the growth room in the conditions mentioned. Unless stated otherwise, cell trays with $3 / 3.5-\mathrm{cm}$ cells were used. Unless stated otherwise, the plant material consisted of 3to 5 -cm long shoots.

In Rubus fruticosus 'Loch Ness', two types of cell trays were used: V1LN, cell trays with $3 / 3.5-\mathrm{cm}$ cells where long as well as short shoots were rooted without being previously separated into categories; V2LN, cell trays with $1 / 1-\mathrm{cm}$ cells where long shoots were rooted; and V3LN, cell trays with $1 / 1-\mathrm{cm}$ cells where short shoots (shorter than $2.5 \mathrm{~cm}$ ) were rooted (Table 3). To establish rooting percentages, the length of root bunches and the average number of roots/plant, 20 cells per experimental treatment, were examined. In Rubus fruticosus 'Chester', the experimental treatments were: V1C, cell trays with cell sizes of $3 / 3.5 \mathrm{~cm}$ in which long ( 3 to $5 \mathrm{~cm}$ ) as well as short $(1.5$ to $2.5 \mathrm{~cm})$ shoots were rooted without being separated into categories; V2C, cell trays with $3 / 3.5-\mathrm{cm}$ cells with long shoots; V3C, cell trays with $1 / 1-\mathrm{cm}$ cells with long shoots; and V4C, cell trays with $1 / 1-\mathrm{cm}$ cells with short shoots (less than $2.5 \mathrm{~cm}$ in length). For data accumulation on survival and measurements, 10 cells/experimental treatment were examined (Table 4).

\section{Ex vitro acclimatization in float} hydroculture of plantlets rooted in vitro

This method was tested for: Rubus idaeus 'Willamette', Lycium barbarum, Amelanchier canadensis 'Rainbow Pillar', Ribes nigrum

Table 2. The characteristics of the water at the exit from Gilău Cluj Processing Station (6 Apr. 2012).

\begin{tabular}{|c|c|c|c|c|}
\hline & Parameters studied & UM & Value obtained & Method of analysis \\
\hline 1 & Turbidity & NTU & 0.69 & SR EN ISO 7027/2001 \\
\hline 2 & $\mathrm{pH}$ & unit $\mathrm{pH}$ & $7.30(20.3)$ & SR ISO $10523 / 2009$ \\
\hline 3 & Free residual chlorine & $\mathrm{mg} \cdot \mathrm{L}^{-1}$ & 0.98 & SR EN 7393-1/ 2002 \\
\hline 4 & Chlorides & $\mathrm{mg} \cdot \mathrm{L}^{-1}$ & 3.68 & SR ISO 9297/ 2001 \\
\hline 5 & Permanganate index & $\mathrm{mg}[\mathrm{O}] / \mathrm{L}$ & 1.48 & SR EN ISO $8467 / 2001$ \\
\hline 6 & Ammonium & $\mathrm{mg} \cdot \mathrm{L}^{-1}$ & $\mathrm{BDL}(\mathrm{LOD}=0.03)$ & SR ISO 7150-1/ 2001 \\
\hline 7 & Nitrites & $\mathrm{mg} \cdot \mathrm{L}^{-1}$ & $\mathrm{BDL}(\mathrm{LOD}=0.02)$ & SR EN 26777/ 2002 \\
\hline 8 & Nitrates & $\mathrm{mg} \cdot \mathrm{L}^{-1}$ & 2.86 & SR ISO $7890-3 / 2000$ \\
\hline 9 & Conductivity & $\mu \mathrm{S} \cdot \mathrm{cm}^{-1}$ & 87.1 & SR EN 27888/97 \\
\hline 10 & Total dissolved substances & $\mathrm{mg} \cdot \mathrm{L}^{-1}$ & 52 & SR EN 27888/97 \\
\hline 11 & Hardness & ${ }^{\circ} \mathrm{G}$ & 2.46 & SR ISO $6059 / 2008$ \\
\hline 12 & Calcium & $\mathrm{mg} \cdot \mathrm{L}^{-1}$ & 11.98 & SR ISO $6058 / 2008$ \\
\hline 13 & Magnesium & $\mathrm{mg} \cdot \mathrm{L}^{-1}$ & 3.42 & SR ISO $6059 / 2008$ \\
\hline 14 & Alcalinity & $\mathrm{mL} \mathrm{HCl} 0,1 \mathrm{~N}$ & 0.57 & SR ISO 9963-1/1997 \\
\hline 15 & Temporary hardness & ${ }^{\circ} \mathrm{G}$ & 1.59 & SR ISO 9963-1/1997 \\
\hline 16 & Bicarbonates & $\mathrm{mg} \cdot \mathrm{L}^{-1}$ & 34.83 & SR ISO 9963-1/1997 \\
\hline 17 & Sulphates & $\mathrm{mg} \cdot \mathrm{L}^{-1}$ & 8.29 & HACH method \\
\hline 18 & Phosphates & $\mathrm{mg} \cdot \mathrm{L}^{-1}$ & 0.04 & SR EN ISO $6878-2008$ \\
\hline 19 & TOC & $\mathrm{mg}[\mathrm{C}] / \mathrm{L}$ & 2.45 & SR EN 1484/2006 \\
\hline 20 & Iron & $\mathrm{mg} \cdot \mathrm{L}^{-1}$ & 0.01 & Merck Kit \\
\hline
\end{tabular}

$\mathrm{TOC}=$ total organic carbon; NTU = nephelometric turbidity units; $\mathrm{BDL}=$ below detection limit; $\mathrm{LOD}=$ limit of detection.

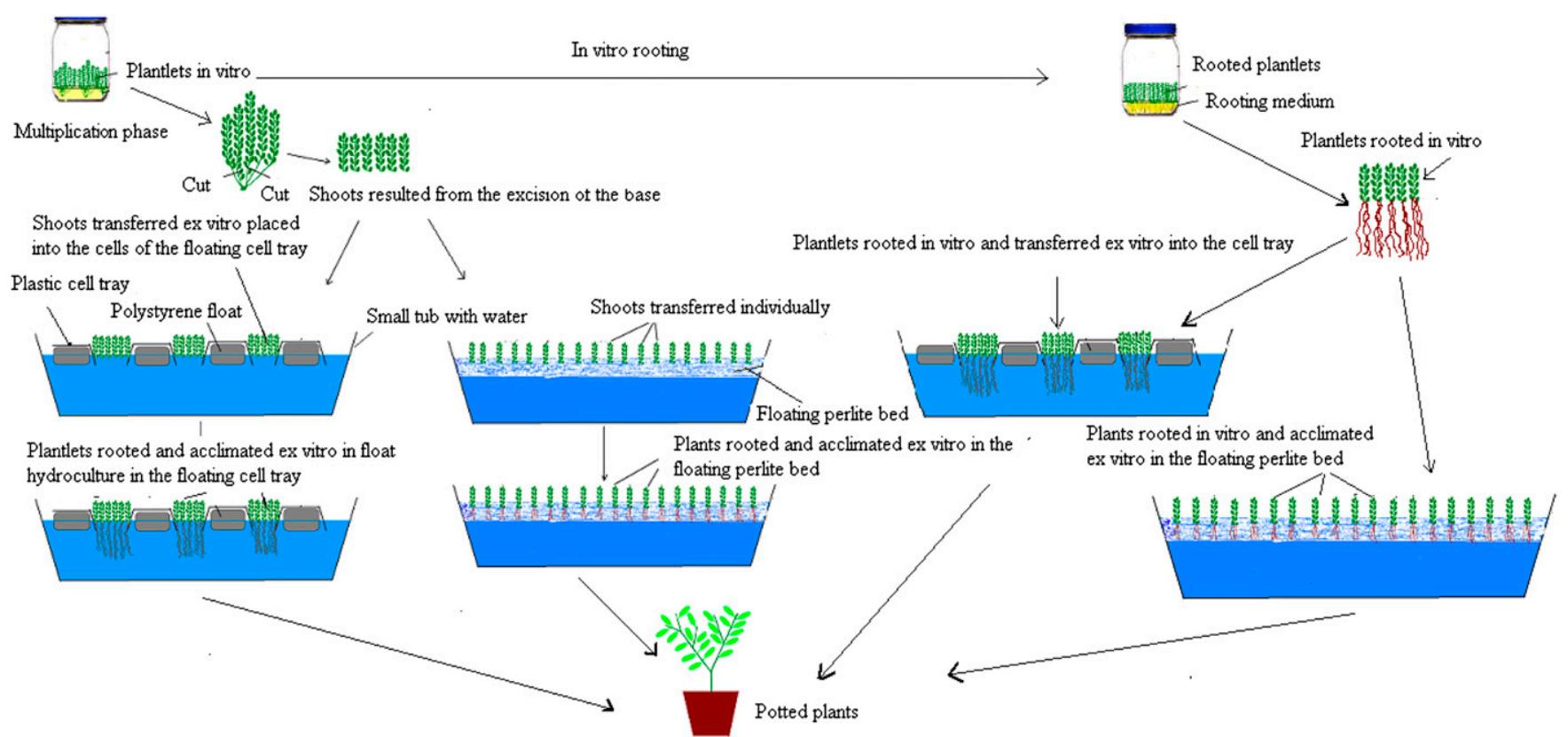

Fig. 1. A scheme representing the methods of ex vitro acclimatization in float hydroculture and in floating perlite. 
Table 3. Ex vitro rooting and acclimatization in float hydroculture in Rubus fruticosus, cv. Loch Ness.

\begin{tabular}{|c|c|c|c|c|c|c|c|}
\hline Treatment & $\begin{array}{l}\text { Total no. of } \\
\text { initial shoots }\end{array}$ & $\begin{array}{l}\text { Total no. of } \\
\text { rooted plants }\end{array}$ & $\begin{array}{l}\text { Initial no. of } \\
\text { shoots/cell }\end{array}$ & $\begin{array}{c}\text { No. of rooted } \\
\text { shoots/cell }\end{array}$ & Rooting (\%) & $\begin{array}{l}\text { Avg length of the } \\
\text { root clump }(\mathrm{cm})\end{array}$ & $\begin{array}{l}\text { Avg no. of } \\
\text { roots/plant }\end{array}$ \\
\hline$\overline{\text { V1LN }}$ & 363 & 257 & 18.15 & 12.85 & 70.79 & 12.15 & 6.42 \\
\hline V2 LN & 103 & 79 & 5.15 & 3.95 & 76.70 & 9.72 & 6.87 \\
\hline V3LN & 102 & 95 & 5.10 & 4.75 & 93.14 & 9.55 & 4.98 \\
\hline
\end{tabular}

Table 4. Ex vitro rooting and acclimatization in float hydroculture in Rubus fruticosus cv. Chester.

\begin{tabular}{lccccc}
\hline Treatment & $\begin{array}{c}\text { Total no. of } \\
\text { initial shoots }\end{array}$ & $\begin{array}{c}\text { Total no. of } \\
\text { rooted plants }\end{array}$ & $\begin{array}{c}\text { Initial no. of } \\
\text { shoots/cell }\end{array}$ & $\begin{array}{c}\text { No. of rooted } \\
\text { plants/cell }\end{array}$ & Rooting (\%) \\
\hline V1C & 240 & 148 & 24 & 14.8 & 61.66 \\
V2C & 117 & 95 & 11.7 & 9.5 & 81.19 \\
V3C & 81 & 57 & 8.1 & 5.7 & 70.37 \\
V4C & 78 & 70 & 7.8 & 7.0 & 89.74 \\
\hline
\end{tabular}

Table 5. Results regarding the ex vitro acclimatization in float hydroculture of the plants rooted in vitro.

\begin{tabular}{lccc}
\hline Species and cultivar & $\begin{array}{c}\text { Total no. } \\
\text { of plants }\end{array}$ & $\begin{array}{c}\text { No. of acclimatized } \\
\text { plants }\end{array}$ & Survival (\%) \\
\hline Rubus idaeus, cv. Willamette & 280 & 234 & 83.57 \\
Ribes nigrum cv. Tisel & 94 & 87 & 92.55 \\
Prunus cerasus $\times$ P. canescens Gisela 5 & 176 & 102 & 57.95 \\
Lycium barbarum Ning Xial & 135 & 127 & 94.07 \\
Amelanchier canadensis Rainbow Pillar & 91 & 81 & 89.01 \\
Drosera capillaris & 32 & 25 & 78.13 \\
Drosera rotundifolia & 50 & 50 & 100 \\
Nephrolepis sp. & 56 & 53 & 94.64 \\
\hline
\end{tabular}

water and stayed humid at the surface. The shoots or in vitro-rooted plantlets were planted, with or without a dibble, into the layer of floating perlite. Optionally, for less vigorous shoots or, for more tender plantlets, partial protection should be ensured by using a transparent lid but without increasing humidity close to $100 \%$. The acclimatization vessels prepared in this way should be kept for 1 to 1.5 months in the growth room or in a greenhouse in temperature conditions similar to the normal weather conditions in May through August $\left(\approx 15{ }^{\circ} \mathrm{C}\right.$ at night and 20 to $25{ }^{\circ} \mathrm{C}$ during the day).

\section{Ex vitro rooting and acclimatization in floating perlite beds of the shoots obtained in the multiplication stage}

In this case, the individual shoots, without roots, excised from plantlets obtained in the multiplication stage were planted into the floating perlite beds at equal distances. This method was tested in these species: Rubus fruticosus 'Chester', Rubus idaeus 'Willamette' and 'Erntesegen', 'Tayberry' (Rubus fruticosus $\times$ Rubus idaeus), Vaccinium corymbosum 'Duke', 'Hannah's Choice', and 'Elliot', Vaccinium macrocarpon 'Pilgrim', Lycium barbarum, Amelanchier canadensis 'Rainbow Pillar', Rosa hybrida 'Cristiana', and Stevia rebaudiana. In most cultivars the number of shoots transferred for ex vitro rooting and the results regarding ex vitro rooting percentages are presented in Table 6 . In Rubus idaeus 'Willamette', there was a series of tests involving three repetitions consisting of three batches of shoots planted into floating perlite beds (total number 535). These consisted of various arrangements of the shoots (Table 7). It was found that the shoots smaller than $2.5 \mathrm{~cm}$ rooted poorly, so a fourth experimental series with two categories of shoots was set up to establish the difference between the rooting percentages of the small vs. long shoots: one category with $3-$ to $5-\mathrm{cm}$ long shoots and one category with $2-$ to $2.5-\mathrm{cm}$ long shoots (Table 8). In Amelanchier canadensis, several benzyladenine (BAP) concentrations were used and the results are presented in Table 9. Based on these results, a second batch with only large, 3- to 5-cm long shoots obtained from 3-month-old cultures on MSs + $2.22 \mu \mathrm{M}$ BAP were used.

Statistical data analysis. For statistical analysis, monofactorial analysis of variance $(P \leq 0.05)$ was used by using the Gnumeric software. Some results contain an E symbol. The number after $E$ represents the number of decimal places that should be moved to the left in the number before $\mathrm{E}$, for example $P=$ $1.388120 \mathrm{E}-005$ is $P=0.00001388$.

In the experiments of Rubus fruticosus ex vitro rooting in floating cell trays, the cells were considered as experimental units and the numerical values of the rooting percentages per each cell were considered. Having in view that the large cells contained a much higher number of shoots than the small cells (Tables 3 and 4), the average values of the length of root clumps, numbers of roots/ plant, were calculated for each cell. Our goal was to investigate the statistical significance of the differences between the experimental treatments regarding rooting percentages, the lengths of root clumps, and the number of roots/plantlet to establish which experimental treatment (large cells or small cells) provided better results and whether there were significant differences between long shoots and short shoots regarding root lengths and the number of roots/plantlet.
In the ex vitro rooting experiment in Rubus idaeus 'Willamette' in floating perlite beds, the plantlets were considered as experimental units and the numbers of roots per each plantlet and the lengths of the root clumps (maximum root lengths) per each plantlet were considered. Thirty-two plants/treatment were investigated. Our goal was to investigate the significance of difference regarding the number of roots/plantlet and root lengths between the two groups of shoots (3- to 5-cm long shoots vs. $2-$ to 2.5 -cm long shoots). In Rosa hybrida 'Cristiana', the plantlets were considered as experimental units similar to $R u$ bus idaeus 'Willamette' and our goal was to investigate whether there were significant differences regarding the number of roots/ plantlet and root lengths by studying three randomly taken samples of 10 plants each.

\section{Ex vitro acclimatization in floating perlite beds of the plantlets rooted in vitro}

In this case the plantlets rooted in vitro in the rooting media presented in Table 1 were planted into floating perlite beds at equal distances: Lycium barbarum, cherry rootstock 'Gisela 5' (Prunus cerasus $\times$ P. canescens). The method was not tested in Drosera capillaris, Drosera rotundifolia, and Nephrolepis sp. as a result of the efficiency and simplicity of the floating cell tray method.

These acclimatization methods are presented graphically in Figure 1.

\section{Results and Discussion}

Ex vitro rooting and acclimatization in float hydroculture of the shoots obtained in the multiplication stage

Rubus fruticosus. The best results for ex vitro rooting and acclimatization in Rubus fruticosus 'Loch Ness' were obtained in the cell trays with $1-\mathrm{cm}$ cells. The short shoots generated shorter roots but the rooting percentage was higher. In both treatments where small cells were used, the rooting and acclimatization percentages were superior to the one where large cells were used (Table 3 ). This may be because, in the treatment with large cells, the short shoots were either totally covered with water or did not get enough ventilation because they were covered by the longer shoots and so they died.

Statistically, the differences regarding root clump length between treatments V2LN (small cells, long shoots) and V3LN (small cells, short shoots) were not significant $(P=$ 0.803830 ) and significant between V1LN (large cells with mixed shoots, long and short) and V2LN $(P=0.000444)$, respectively, between V1LN and V3LN $(P=0.000273)$. The 
Table 6. Results regarding the ex vitro rooting and acclimatization in floating perlite beds of the shoots obtained in the in vitro multiplication stage.

\begin{tabular}{|c|c|c|c|}
\hline Species/cultivar & $\begin{array}{l}\text { Total no. } \\
\text { of shoots }\end{array}$ & $\begin{array}{l}\text { No. of acclimatized } \\
\text { plants }\end{array}$ & Rooting (\%) \\
\hline Rubus fruticosus/Chester & 57 & 54 & 94.73 \\
\hline Rubus idaeus /Erntesegen & 218 & 204 & 93.57 \\
\hline Rubus fruticosus $\times$ Rubus idaeus Tayberry & 160 & 125 & 78.12 \\
\hline Vaccinium corymbosum/Duke & 186 & 183 & 98.38 \\
\hline Elliot & 155 & 131 & 84.52 \\
\hline Hannah's Coice & 92 & 87 & 94.57 \\
\hline Vaccinium macrocarpom/Pilgrim & 54 & 53 & 98.15 \\
\hline Rosa hybrida /Cristiana & 81 & 71 & 87.65 \\
\hline
\end{tabular}

Table 7. The ex vitro rooting percentages in three large batches of Rubus idaeus cultivar Willamette transferred ex vitro into floating perlite beds.

\begin{tabular}{lcccc}
\hline Vessel no. & Rows $\times$ shoots & $\begin{array}{c}\text { Total no. of shoots } \\
\text { transferred ex vitro }\end{array}$ & Total no. of rooted plants & Rooting (\%) \\
\hline 1 & $11 \times 13$ & 143 & 124 & 86.71 \\
2 & $14 \times 13$ & 182 & 156 & 85.71 \\
3 & $14 \times 15$ & 210 & 152 & 72.38 \\
\hline
\end{tabular}

Table 8. Results regarding the ex vitro rooting and acclimatization in floating perlite beds obtained in the in vitro multiplication stage, categorized by shoot length in raspberry 'Willamette'.

\begin{tabular}{lcccccc}
\hline Treatment & Total & Rooted & $\begin{array}{c}\text { Rooting } \\
(\%)\end{array}$ & $\begin{array}{c}\text { Plant } \\
\text { ht }(\mathrm{cm})\end{array}$ & $\begin{array}{c}\text { Root } \\
\text { length }(\mathrm{cm})\end{array}$ & No. of roots \\
\hline $\begin{array}{l}1.2-\text { to } 2.5-\mathrm{cm} \text { long } \\
\text { shoots }\end{array}$ & 51 & 32 & 62.75 & 3.42 & 2.57 & 6 \\
$\begin{array}{l}2 . \\
\begin{array}{l}\text { Shoots } 3 \mathrm{~cm} \text { or } \\
\text { greater }\end{array}\end{array}$ & 53 & 52 & 98.11 & 5.23 & 6.74 & 8.69 \\
$\begin{array}{l}P \text { values } \\
\text { Statistical significance }\end{array}$ & & & - & $\begin{array}{c}7.57 \mathrm{E}-10 \\
\text { Very significant }\end{array}$ & $\begin{array}{c}5.53 \mathrm{E}-08 \\
\text { Very significant }\end{array}$ & $\begin{array}{c}0.004217 \\
\text { Very significant }\end{array}$ \\
\hline
\end{tabular}

Table 9. The ex vitro rooting and acclimatization in floating perlite beds of the shoots obtained in the multiplication stage in Amelanchier canadensis 'Rainbow Pillar'.

\begin{tabular}{lcccc}
\hline Multiplication media & Shoot sizes & $\begin{array}{c}\text { Total no. } \\
\text { of explants }\end{array}$ & $\begin{array}{c}\text { No. of rooted } \\
\text { explants }\end{array}$ & Rooting (\%) \\
\hline MSm $+4.44 \mu \mathrm{M}$ BAP & 1.5 to $2 \mathrm{~cm}$ & 27 & 10 & 37.04 \\
MSm $+2.22 \mu \mathrm{M}$ BAP & 3 to $5 \mathrm{~cm}$ & 35 & 34 & 97.14 \\
$\mathrm{MSm}+2.22 \mu \mathrm{M}$ BAP & 1.5 to $2 \mathrm{~cm}$ & 24 & 4 & 16.67 \\
MSm $+4.44 \mu \mathrm{M}$ BAP & 1.5 to $2 \mathrm{~cm}$ & 78 & 28 & 35.90 \\
\hline
\end{tabular}

$\mathrm{MSm}=$ modified Murashige and Skoog gelled with agar; BAP $=$ benzyladenine.

differences regarding average root number/ plant were not significant $(P=0.197558)$ between V1LN and V2LN and significant between V2LN and V3LN $(P=0.000259)$ as well as V1LN and V3LN $(P=0.000438)$. The differences regarding rooting percentages/ cell were significant $(P=0.011359)$ between treatments V2LN and V3LN (the treatments with small cells) and not significant between V1LN and V2LN $(P=0.553373)$ and significant between V1 and V3 $(P=1.388120 \mathrm{E}-005)$.

In Rubus fruticosus 'Chester', it should be noted that if the shoots derived from the multiplication stage were not separated into categories according to size and the small shoots were left among the long shoots, the small shoots were suppressed by the larger ones or they were totally submerged in the water and died, so in this case, rooting and survival percentage was the lowest $(61.66 \%)$. By using small cells and separating the shoots into two categories similar to 'Loch Ness', the results regarding rooting percentages were superior (Table 4).

The differences regarding rooting percentages were significant $(P=0.003552)$ between
V1C (large cells with mixed shoots, long and short); significant $(P=0.00880)$ among V2C (large cells with long shoots), V1C, and V3C (small cells with long shoots); and not significant $(P=0.17452)$ between V1C and V4C (small cells with short shoots). The differences were not significant between V2C and $\mathrm{V} 3 \mathrm{C}$.

In Rubus fruticosus, in both cultivars there were superior rooting percentages in the treatments with short shoots and small cells. This proves that the short shoots (less than $3 \mathrm{~cm}$ ) are very viable explants and should be transferred separately into small cells, not together with the long shoots.

Rosa hybrida. This method proved to be easy and very effective for 'Red Bells' and 'Cristiana'. The shoots from the multiplication stage were rooted and acclimatized in 1 month. In 'Red Bells', from the initial number of 45 shoots, 42 rooted ( $93.33 \%$ rooting). In 'Cristiana', a total of 99 shoots were transferred ex vitro and 86 rooted well, six of them rooted poorly (one to two roots 1 to 2 $\mathrm{cm}$ in length), and seven did not root (three of these eventually died). The percentage of well-rooted plants was $86.86 \%$ and overall rooting percentage was $92.92 \%$.

In all the cultivars in species Rubus idaeus, Lycium barbarum, Amelanchier canadensis, Stevia rebaudiana, cherry rootstock 'Gisela 5' (Prunus cerasus $\times$ Prunus canescens), and 'Tayberry' (Rubus fruticosus $\times$ Rubus idaeus), all the non-rooted shoots derived from the multiplication stage that were transferred ex vitro in floating cell trays died in 3 to $7 \mathrm{~d}$. Figure 2 shows 'Chester' blackberry plantlets rooted directly ex vitro and acclimatized in float hydroculture in a floating cell tray.

\section{Ex vitro acclimatization in float}

\section{hydroculture of plantlets rooted in vitro}

The survival percentages by this method are presented in Table 5.

In Rubus idaeus 'Willamette', all three samples of 10 cells from the three repetitions tested yielded survival percentages of more than $80 \%(86.05 \%, 80.61 \%$, and $84.38 \%$, respectively). The overall acclimatization percentage was $83.57 \%$. The plantlets got acclimatized in $15 \mathrm{~d}$.

In Ribes nigrum 'Tisel', there was a high survival percentage and the plantlets grew rapidly in size. In 3 weeks they doubled their height. Unlike our results, Ružić and Lazić (2006) rooted in vitro the shoots obtained in the multiplication stage, in black currant 'Ččanska crna', in similar conditions and then the rooted plantlets were acclimatized in the mist chamber but the survival percentage was only $40 \%$. Our results regarding Ribes nigrum ex vitro acclimatization are similar to earlier Ribes nigrum acclimatization results obtained also with tap water and plastic trays (Fira and Clapa, 2009). Our simple yet efficient ex vitro acclimatization method is recommended for experimenting the ex vitro acclimatization of several valuable Ribes nigrum cultivars

'Gisela 5' (Prunus cerasus $\times$ P. canescens) is the species in which the lowest survival percentages were obtained by this method $(58 \%)$, but the results obtained by classical acclimatization methods (by using solid substrates and high air humidity) were similar with low survival percentages: $36.4 \%$ (Šiško, 2011) or 61.8\% (Vujović et al., 2012). In Lycium barbarum, besides the high survival percentage (94\%), the plantlets grew in size in the acclimatization stage and had a healthy appearance. It was noticed that the plantlets that died were small ones (size below $3 \mathrm{~cm}$ ). In Amelanchier canadensis 'Rainbow Pillar', the overall survival percentage of the plantlets rooted in MSs with $0.5 \mathrm{mg} \cdot \mathrm{L}^{-1}$ indole-butyric acid and then acclimatized in float hydroculture was $89.01 \%$; in some cells, all the plantlets survived. In Drosera rotundifolia, the plantlets grew in size and they had a healthy appearance. The inflorescences grew in height during the acclimatization stage. Nephrolepis sp. had a high survival percentage in the greenhouse despite poor protection against sunlight (double layer of shading net). Some leaves were slightly sunburnt but the plantlets got acclimatized successfully. Figure 3 shows several species rooted in vitro 
and acclimatized ex vitro in float hydroculture in cell trays.

Ex vitro rooting and acclimatization in floating perlite beds of the shoots obtained in the in vitro multiplication stage

The rooting and acclimatization percentages obtained by this method are presented in Table 6.

In Rubus fruticosus 'Chester', from the total number of 57 shoots, 52 rooted well and two were poorly rooted.

In Rubus idaeus 'Willamette', in the first three batches of shoots transferred for ex vitro rooting, the rooting percentages were high
(Table 7), 432 of the total number of 535 shoots rooted, and the overall rooting percentage was $80.75 \%$. In the fourth test, the long shoots gave superior results from all points of view: rooting percentage, plant height, length of root clump, and number of roots/ plant (Table 8). In this fourth batch, the overall rooting percentage was $80.76 \%$. As a result of its efficiency and ease of use, in Rubus idaeus, direct ex vitro rooting in floating perlite beds is recommended. In vitro rooting followed by the ex vitro acclimatization of rooted plantlets is obsolete.

The Lycium barbarum plantlets obtained in the multiplication stage could not be rooted and acclimatized by this technique; all the shoots died a few days after being planted into floating perlite.

In Vaccinium corymbosum 'Duke', the first batch of 55 shoots had $100 \%$ rooting percentage and the second batch of 131 shoots had $97.71 \%$ rooting percentage.

The rooting and acclimatization percentages obtained in Vaccinium corymbosum (Table 6) were similar to the ones obtained by Isutsa et al. (1994) in 'Berkeley' and 'Northsky'. They obtained more than 99\% survival percentage by rooting in growth chambers with artificial fog and artificial light in a mixture of peat and perlite 1:1 volume-tovolume ratio, the cultures were incubated in the growth chambers for 7 weeks, and they
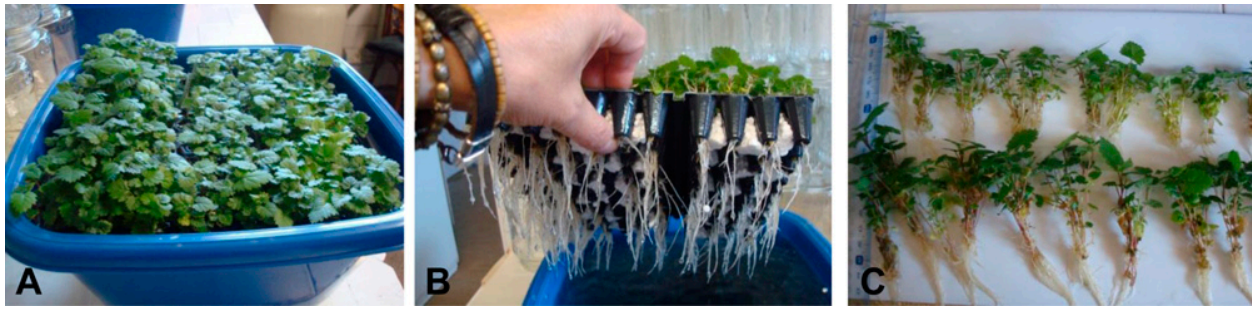

Fig. 2. Ex vitro rooting and acclimatization in float hydroculture of the shoots obtained in the in vitro multiplication stage. (A) Thornless blackberry cv. Chester in the ex vitro rooting and acclimatization stage in float hydroculture (small tub); (B) plantlets rooted and acclimatized, still in the floating cell trays; (C) rooted plantlets.
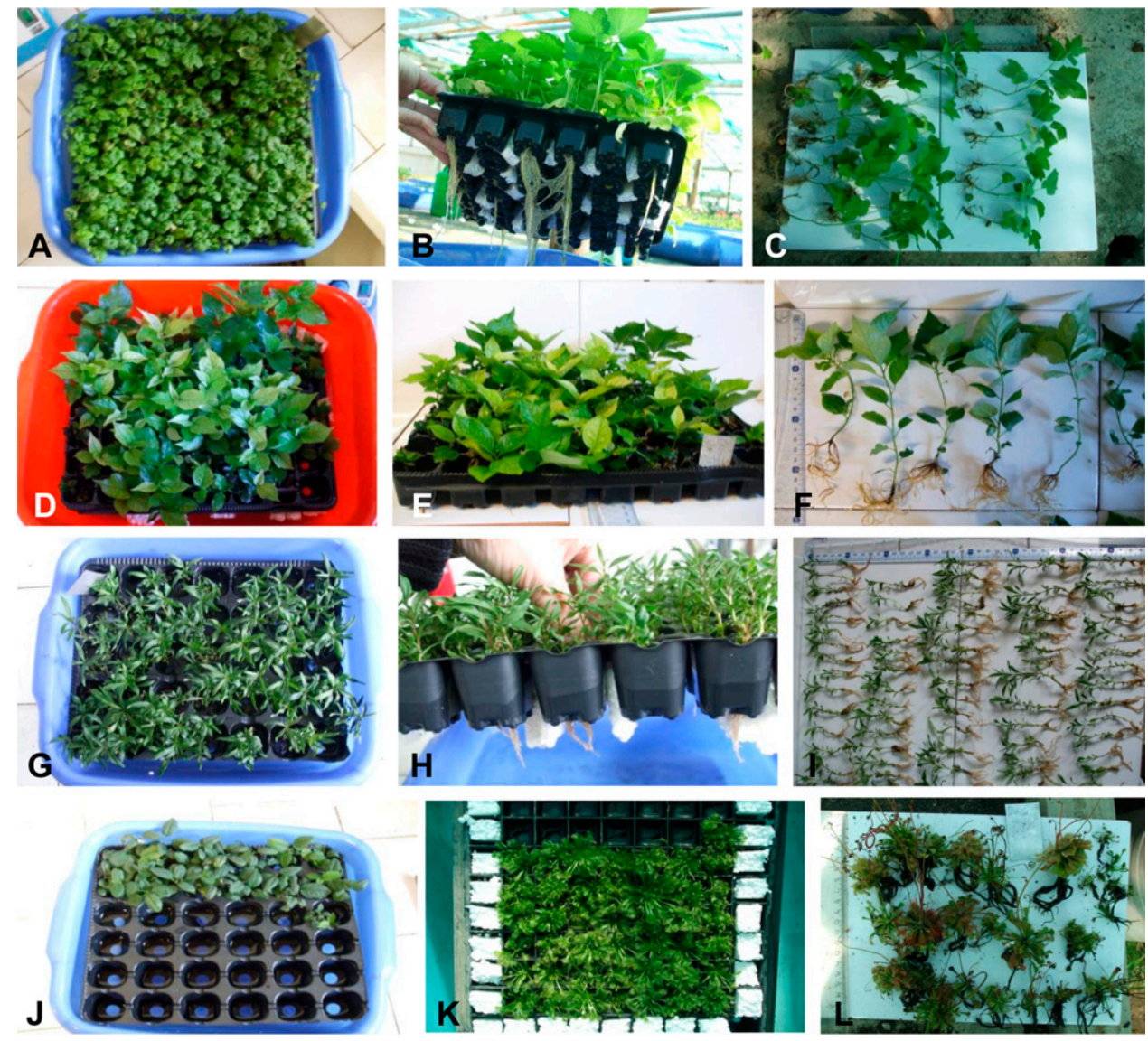

Fig. 3. Ex vitro acclimatization in float hydroculture of plantlets rooted in vitro. (A) Rubus idaeus cv. Willamette; (B) Ribes nigrum 'Tisel' acclimatized in a floating cell tray; (C) Ribes nigrum 'Tisel' - plants acclimatized in float hydroculture for 1 month; (D) 'Gisela 5' (Prunus cerasus $\times$ Prunus canescens) in the acclimatization stage in the tub; (E) 'Gisela 5' (Prunus cerasus $\times$ Prunus canescens) in the cell tray; (F) 'Gisela 5' (Prunus cerasus $\times$ Prunus canescens) plants acclimatized in float hydroculture; (G) Goji berry plantlets rooted in vitro and cultured in float hydroculture in the acclimatization stage; (H) Lycium barbarum in the cell tray; (I) Lycium barbarum plantlets acclimatized in float hydroculture, taken out from the cells; (J) A. canadensis in float hydroculture; (K) Drosera rotundifolia in float hydroculture; (L) Drosera capillaris plantlets acclimatized ex vitro. 
were transferred to a plastic tunnel with artificial fog for a period of 2 weeks, where the optimal light intensity proved to be $100 \pm$ $20 \mu \mathrm{mol} \cdot \mathrm{m}^{-2} \cdot \mathrm{s}^{-1}$, which strongly stimulated root growth.

In Vaccinium macrocarpon, the method of ex vitro rooting and acclimatization in floating perlite gave superior results as compared with the classical methods. Marcotrigiano and McGlew (1991) tested direct ex vitro rooting of the Vaccinium macrocarpon shoots obtained in the multiplication stage; they used plastic vessels filled with two types of potting mix: Redi-Earth as well as peat + sand mixture in 1:1 (v/v). The vessels were covered with two types of plastic lids: transparent and translucent ones. There were no significant differences in rooting in the two types of potting mix. The rooting efficiency was $84.7 \% \pm 2.4 \%$ under the translucent lids and $96.5 \% \pm 1.3 \%$ under the transparent ones.

In Amelanchier canadensis 'Rainbow Pillar', the rooting and acclimatization percentages of the shoots obtained in the multiplication stage depended on the BAP concentration used in the multiplication stage and also on the sizes of the shoots that were obtained. The highest rooting and acclimatization percentage was obtained in the $3-$ to $5-\mathrm{cm}$ long shoots resulted from the culture media with $2.22 \mu \mathrm{M}$ BAP (Table 9). In the second batch of 3- to 5-cm long shoots, $90.29 \%$ rooting percentage was obtained ( 93 rooted plantlets from the initial 103 shoots).

In Rosa hybrida 'Cristiana', biometrical studies were made regarding shoot length, the length of the root clump, and the number of roots/plant in the three samples of 10 plants each, randomly taken for measurements. The average length of root clumps was $11.74 \mathrm{~cm}$, average shoot length was $4.56 \mathrm{~cm}$, and the average number of roots/plant was 5.0. There were no significant statistical differences regarding the number of roots/plantlet among the three samples $(P=0.7190)$.

Figure 4 shows several species rooted directly ex vitro and acclimatized in floating perlite beds.

\section{The ex vitro acclimatization in floating perlite beds of the plantlets rooted in vitro}

This method was applied for the ex vitro acclimatization of Lycium barbarum and 'Gisela 5' (Prunus cerasus $\times$ Prunus canescens) rooted in vitro.

In 'Gisela 5' cherry rootstock, planting the in vitro-rooted plants into the layer of floating perlite proved to be relatively difficult, but the high survival percentage compensated for this disadvantage. The survival percentage was $67.24 \%$ (39 plantlets out of the initial 58) and it was superior to the results obtained in floating cell trays. The roots also grew vigorously.

In Lycium barbarum, the survival percentage was $74.73 \%$ (68 survived out of the initial 91 plantlets), less than in hydroculture in floating cell trays. Figure 5 shows 'Gisela 5 ' cherry rootstock and Lycium barbarum plants rooted in vitro and acclimatized ex vitro in floating perlite beds.

Having in view the efficiency of direct ex vitro rooting in Rubus idaeus 'Willamette' in floating perlite beds, this ex vitro rooting and acclimatization method is recommended instead of the in vitro rooting followed by ex vitro acclimatization in floating cell trays, which in this case does not have much practical importance. According to our results, the longer shoots gave superior rooting percentages as compared with the shorter shoots (Table 8). However, it is recommended that the shorter shoots should also be used to save plant material, because the in vitro proliferation rates in Rubus idaeus are relatively mediocre. The overall rooting and survival percentage of $80.76 \%$ was not superior to the survival percentage obtained in the experiment of ex vitro acclimatization of 'Willamette' plantlets rooted in vitro (Table 5), but the use of direct ex vitro rooting in floating perlite beds eliminates the need for the in vitro rooting stage, which is
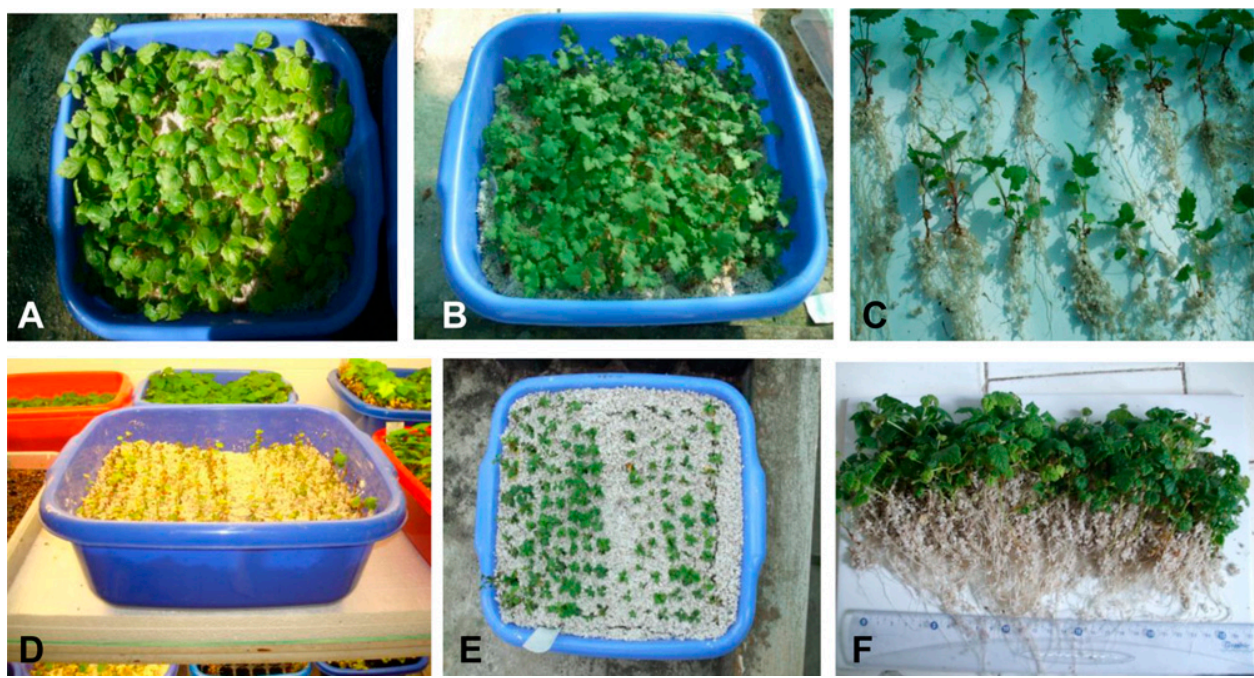

Fig. 4. Ex vitro rooting and acclimatization in floating perlite bed of the shoots obtained in the in vitro multiplication stage: (A) Rubus idaeus 'Norna'; (B) 'Tayberry' (Rubus fruticosus $\times$ Rubus idaeus); (C) 'Tayberry' plantlets rooted and acclimatized in floating perlite; (D) Vaccinium corymbosum in floating perlite; (E) Amelanchier canadensis; (F) Rubus idaeus 'Willamette' rooted and acclimatized in floating perlite.
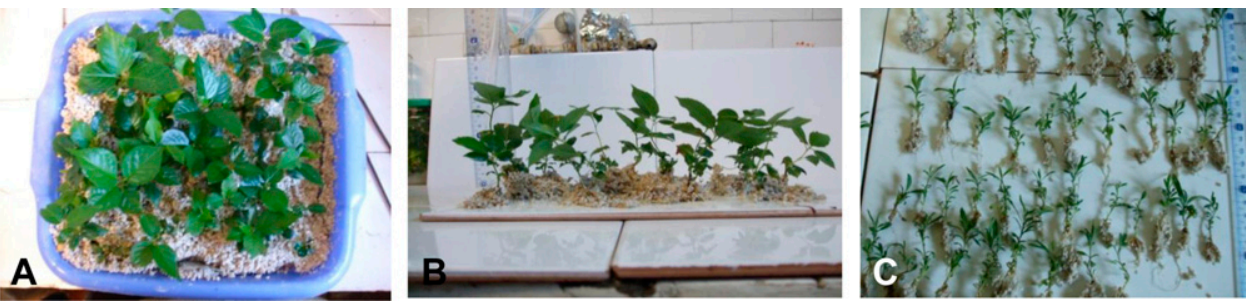

Fig. 5. Ex vitro acclimatization in floating perlite of the plantlets rooted in vitro: (A) 'Gisela 5' (Prunus cerasus $\times$ Prunus canescens) in floating perlite; (B) 'Gisela 5' (Prunus cerasus $\times$ Prunus canescens) - plantlets acclimatized ex vitro, taken out of the floating perlite; (C) Lycium barbarum plantlets rooted in vitro and acclimatized ex vitro in floating perlite. 
labor-intensive, needs additional vessels and media for in vitro culture, and also an additional 1-month rooting stage. In Rubus idaeus 'Erntesegen' and in Rubus fruticosus $\times$ Rubus idaeus 'Tayberry' as well as Rosa hybrida, it was not the case to compare the rooting efficiency of long vs. short shoots as a result of the very good vigor and uniformity of the shoots and as a result of the prevalence of long shoots regenerated in the in vitro multiplication stage.

In Amelanchier canadensis, the ex vitro acclimatization in floating cell trays of the plantlets rooted in vitro proved to be very efficient, however, having in view the high rooting percentage of the longer shoots (Table 9) obtained in the plantlets cultured on media with $2.22 \mu \mathrm{M}$ BAP and, also, having in view the very high numbers of shoots regenerated in the multiplication stage (unpublished results), it is recommended to avoid the in vitro rooting stage and to use instead direct ex vitro rooting in floating perlite beds, like in Rubus idaeus 'Willamette'. Nevertheless, as a result of the relatively low rooting percentages of short shoots, it is not recommended to use these, also having in view the large number of long, well-developed shoots available. In this case, in Amelanchier canadensis, we found that it was more important to save space and labor in the ex vitro rooting stage by using only long shoots than to save plant material by using the long as well as short, lesser developed shoots.

In Rubus fruticosus, in vitro rooting was not required as a result of the effectiveness of direct ex vitro rooting (Fira et al., 2011). For optimal ex vitro rooting and survival percentages, we recommend ex vitro transfer by placing the long, 3- to $5-\mathrm{cm}$ shoots and the shorter shoots separately into small cells instead of placing them randomly together in large cells. This approach yielded superior rooting percentages in both 'Loch Ness' and 'Chester' (Tables 3 and 4). In Rubus fruticosus 'Chester', having in view the far superior rooting percentage obtained in a floating perlite bed, the latter method could be a very good alternative for direct ex vitro rooting. It is recommended to test this technique for other Rubus fruticosus cultivars as well.

In Rosa hybrida 'Cristiana', similar results were obtained regarding direct ex vitro rooting percentages in both the floating cell tray and floating perlite bed methods. Having in view the greater simplicity and ease of use of the floating cell trays, we recommend it for this rose cultivar. We also recommend the testing of the mentioned direct ex vitro rooting techniques for many other rose species and cultivars.

In Vaccinium macrocarpon and Vaccinium corymbosum, ex vitro rooting and acclimatization in floating perlite beds was an absolute success. In both species, this simple technique ensured very high rooting percentages (Table 6).

In Lycium barbarum, in vitro rooting followed by ex vitro acclimatization in floating cell trays is recommended as a result of the ease and efficiency of this method, because direct ex vitro rooting in float hydroculture and in floating perlite beds did not yield positive results.

In Nephrolepis sp., in vitro rooting was necessary because in vitro culture on multiplication media with BAP provided a large number of plantlets that were not developed enough. On the hormone-free media, the plantlets rooted very well and they grew larger, several centimeters in size, and they became normally developed.

In Drosera rotundifolia and Drosera capillaris, it was not the case to transfer non-rooted plantlets ex vitro, because in vitro multiplication and in vitro rooting took place on the same hormone-free media. The results obtained by using float hydroculture in floating cell trays, in Drosera rotundifolia and Nephrolepis sp., are similar to the ones obtained by Fira and Clapa (2009) in an earlier experiment using plastic trays containing tap water.

\section{Conclusions}

The acclimatization methods presented in this article eliminate the necessity of using special, sophisticated installations for air humidification. Instead of such facilities, usual growth rooms and general-purpose greenhouses can be used.

These acclimatization methods are cheap and easy, they can be done by using locally available materials, they do not need fertilizers, plant growth regulators, or any other type of biostimulators, and they do not require water oxygenation by bubbling. They do not even require reliable irrigation systems, because the constant availability of water is ensured by its presence in the tubs. These methods save space, especially when using floating cell trays, into which a high number of plantlets or shoots can be put. When using growth rooms, horizontal area space can be economized by emplacing the small tubs on shelves vertically. Because they do not require special equipment like air humidifiers, our methods are safer in case of technical problems.

As a result of their simplicity and effectiveness, our ex vitro acclimatization techniques have a great potential for application on a large scale in the production of horticultural planting material by micropropagation and, also, in the micropropagation of some rare, endangered plant species, because they are efficient alternatives to the acclimatization methods used today. As a result of this fact, it is recommended that research should be done to establish some pilot stations in greenhouses, tunnels, and growth rooms to test them on a larger scale.

Our radically new ex vitro acclimatization techniques could even be used in other areas of plant biotechnology, for example, for acclimatization of transgenic plants or new, valuable mutants regenerated in vitro. The new techniques we presented could serve as a starting point for several important innovations and inventions in the domain of plant biotechnology.

\section{Literature Cited}

Bobrowski, V.L., P.C. Mello-Farias, and J.A. Peters. 1996. Micropropagation of blackberries (Rubus sp.) cultivars. Rev. Bras. De Agrociencia 2:17-20.

Cristea, V. 2010. In vitro photoautotrophic cultures of endemic and endangered Dianthus species from Romania [in Romanian]. Todesco, ClujNapoca, Romania.

Erig, A.C. and M.W. Schuch. 2005. Tipo de luz na multiplicacao in vitro de framboeseira (Rubus idaeus L.) Batum. Rev. Bras. Frutic. Jaboticabal 27:488-490.

Fira, A. and D. Clapa. 2009. Ex-vitro acclimation of some horticultural species in hydroculture. Bulletin UASVM Horticulture 66: 44-50.

Fira, A., D. Clapa, and C. Plopa. 2009. Micropropagation of blackberry cultivars Thornless evergreen. Proceedings RIFG Piteşti XXV: 213-221.

Fira, A., D. Clapa, and E. Rakosy-Tican. 2011. In vitro propagation of the thornless blackberry cultivar 'Loch Ness' Bulletin UASVM Horticulture. 68:39-46.

Hazarika, B.N. 2003. Acclimatization of tissuecultured plants. Curr. Sci. 85:1704-1712.

Isutsa, D.K., M.P. Pritts, and K.W. Mudge. 1994. Rapid propagation of blueberry plants using ex vitro rooting and controlled acclimatization of micropropagules. HortScience 29:1124 1126.

Lloyd, G. and B. McCown. 1981. Commerciallyfeasible micropropagation of Mountain laurel, Kalmia latifolia, by use of shoot tip culture. Intl. Plant Prop. Soc. Proc. 30:421427.

Marcotrigiano, M. and S.P. McGlew. 1991. A twostage micropropagation system for cranberries. J. Amer. Soc. Hort. Sci. 116:911-916.

Murashige, T. and F. Skoog. 1962. A revised medium for rapid growth and bioassays with tobacco tissue culture. Physiol. Plant. 15:473497.

Najaf-Abadi, A.J. and Y. Hamidoghli. 2009. Micropropagation of thornless trailing blackberry (Rubus $s p$.) by axillary bud explants. Austral. J. of Crop Science 3:191-194.

Peek, D.R. and T.D. Reed. 2008. Greenhouse transplant production, burley tobacco production guide. Virginia State University, Virginia Cooperative Extension, Publication 436-050.

Radmann, E.B., E.D. Gonçalves, and G.R. De Luces Fortes. 2003. Indolbutiric acid concentrations and dark period on the in vitro rooting of blackberry (Rubus sp.), Cv. Ébano. Rev. Bras. Frutic., Jaboticabal-SP. 25:124126.

Reed, T.D. 2009. Float greenhouse tobacco: Transplant production guide. Virginia Cooperative Extension, publication 436-051.

Rohr, R., I. Iliev, A. Scaltsoyiannes, and P. Tsoulpha. 2003. Acclimatization of Micropropagated Forest Trees, Proc. 1st IS on Accl. \& Estab. Microprop. Plants. Eds. A.S. Economou \& P.E. Read. Acta Hort. 616:59-76.

Ross, D.S. and K.M. Teffeau. 1995. Greenhouse float systems for transplant production. Maryland Cooperative Extension, Fact Sheet 690.

Ružić, D. and T. Lazić. 2006. Micropropagation as means of rapid multiplication of newly developed blackberry and black currant cultivars. Agr. Conspec. Sci. 71:149-153.

Ružić, D. and T. Lazić. 2007. Organogenesis in vitro from the leaf of blackberry cv. Čačanska Bestrna. Genetika 39:69-78. 
Sheikh, B.A. 2006. Hydroponics: Key to sustain agriculture in water stressed and urban environment. Pak. J. Agr., Agril. Engg. Vet. Sc. 22:52-57.

Šiško, M. 2011. In vitro propagation of 'Gisela 5' (Prunus cerasus $\times P$. canescens). Agricultura 8:3134.

Sweat, M., R. Tyson, and R. Hochmuth. 2003. Building a floating hydroponic garden. Horti- cultural Department, Florida Cooperative Extension Service, Institute of Food and Agricultural Sciences, University of Florida, HS-943.

Tyson, R.V., J.M. White, and K.V. King. 1999. Outdoor floating hydroponic systems for leafy salad crop and herb production. Proc. Fla. State. Hort. Soc. 112:313-315.
Tromble, F. 2011. African Violet-Acclimatization (2011). Jan. 2013. <http://www.youtube.com/ watch? $\mathrm{v}=\mathrm{EOCFUqJ} 4 \mathrm{QPE}>$.

Vujović, T., Dj. Ružić, and R. Cerović. 2012. In vitro shoot multiplication as influenced by repeated subculturing of shoots of contemporary fruit rootstocks. Hort. Sci. (Prague) 39: 101-107. 